\title{
Morphologic analysis, by means of scanning electron microscopy, of the effect of Er:YAG laser on root surfaces submitted to scaling and root planing
}

\section{Análise morfológica, através de microscopia eletrônica de varredura, da ação do laser de Er:YAG em superfícies radiculares submetidas à raspagem e aplainamento radicular}

\author{
Letícia Helena Theodoro* \\ Valdir Gouveia Garcia** \\ Patrícia Haypek*** \\ Denise Maria Zezell ${ }^{* * * *}$ \\ Carlos de Paula Eduardo*****
}

\begin{abstract}
The purpose of this study was to morphologically evaluate, by means of scanning electron microscopy, the effects of Er:YAG laser on the treatment of root surfaces submitted to scaling and root planing with conventional periodontal instruments. Eighteen root surfaces $(n=18)$, which had been previously scaled and planed, were assigned to 3 groups $(n=6)$. The control Group (G1) received no further treatment; Group 2 (G2) was irradiated with Er:YAG laser $(2.94 \mu \mathrm{m})$, with $47 \mathrm{~mJ} / 10 \mathrm{~Hz}$, in a focused mode with air/water spray during $15 \mathrm{~s}$ and with $0.57 \mathrm{~J} / \mathrm{cm}^{2}$ of fluency per pulse; Group 3 (G 3) was irradiated with Er:YAG laser $(2.94 \mu \mathrm{m})$, with $83 \mathrm{~mJ} / 10 \mathrm{~Hz}$, in a focused mode with air/water spray during $15 \mathrm{~s}$ and with $1.03 \mathrm{~J} / \mathrm{cm}^{2}$ of fluency per pulse. We concluded that the parameters adopted for Group 3 removed the smear layer from the root surface, exposing the dentinal tubules. Although no fissures, cracks or carbonized areas were observed, an irregular surface was produced by Er:YAG laser irradiation. Thus, the biocompatibility of the irradiated root surface, within the periodontal healing process, must be assessed.
\end{abstract}

DESCRIPTORS: Lasers; Dental scaling; Periodontics; Smear layer.

RESUMO: O objetivo do presente estudo foi analisar morfologicamente, através de microscopia eletrônica de varredura, os efeitos do laser de Er:YAG no tratamento de superfícies radiculares submetidas à raspagem e aplainamento radicular com instrumentos manuais. Foram utilizados 18 espécimes $(n=18)$ de superfícies radiculares que após ser submetidos à raspagem e aplainamento radicular foram divididos em 3 grupos $(\mathrm{n}=6)$. O grupo controle $(\mathrm{G} 1)$ não sofreu nenhum tratamento; Grupo 2 (G2) foi irradiado com laser de Er:YAG $(2,94 \mu \mathrm{m}) 47 \mathrm{~mJ} / 10 \mathrm{~Hz}$, focalizado,com refrigeração à água durante $15 \mathrm{~s}$ e fluência de pulso de $0,57 \mathrm{~J} / \mathrm{cm}^{2}$; Grupo 3 (G3) foi irradiado com laser de Er:YAG $(2,94 \mu \mathrm{m}), 83 \mathrm{~mJ} / 10 \mathrm{~Hz}$, focalizado, com refrigeração à agua durante $15 \mathrm{~s}$ e fluência de pulso de $1,03 \mathrm{~J} / \mathrm{cm}^{2}$. Através da análise dos resultados podemos concluir que o laser de Er:YAG nos parâmetros utilizados no G3 promove a remoção de "smear layer" da superfície radicular e exposição dos túbulos dentinários, porém o laser promove aspecto irregular na superfície, apesar de não demonstrar crateras, fendas, fraturas e carbonização, necessitando de estudos que demonstrem a biocompatibilidade desta superfície no processo de reparo periodontal.

DESCRITORES: Lasers; Raspagem dentária; Periodontia; Camada de esfregaço.

\section{INTRODUCTION}

Mechanical root therapy aims at removing the etiologic agents responsible for periodontal diseases caused by inflammatory processes. In the last few years, several treatment alternatives have been presented to compensate the inherent limita- tions to mechanical root therapy in the periodontal treatment. Both in vitro ${ }^{6,8,9,10,19,20,24,28,30}$ and in vivo ${ }^{18,26}$ studies have emphasized the conditioning of root surfaces by means of different methods as a coadjutant step to the scaling and root planning procedure. It aims at reducing the number of microorganisms on the root surface in order to enable

\footnotetext{
*Master in Lasers in Dentistry, Energetics and Nuclear Research Institute, PhD Student in Periodontics; **Chair Professor, Department of Periodontics - School of Dentistry of Araçatuba, São Paulo State University.

*** Master in Restorative Dentistry, School of Dentistry; ****Associate Researcher, Energetics and Nuclear Research Institute;

${ }^{* * * * *}$ Chair Professor, Department of Restorative Dentistry, School of Dentistry - University of São Paulo.
} 
Theodoro LH, Garcia VG, Haypek P, Zezell DM, Eduardo C de P.Morphologic analysis, by means of scanning electron microscopy, of the effect of Er:YAG laser on root surfaces submitted to scaling and root planing. Pesqui Odontol Bras 2002;16(4):308-312.

the regeneration of the structures damaged by the periodontal disease.

The reduction of bacteria on the root surface is not effectively accomplished with the utilization of the chemical agents described in the literature, which are effective in removing the smear layer. Clinical studies have not demonstrated significant effects regarding the utilization of these agents in the periodontal healing process ${ }^{11,12,13}$.

Some authors have demonstrated the effectiveness of Er:YAG laser in removing calculus from the root surface without causing thermal damage $e^{4,5,15,16,21,23,29}$. However, it is not as effective as other instruments ${ }^{5}$. Despite these facts, there are few papers on the utilization of Er:YAG laser as a coadjutant in root mechanical therapy.

According to these facts and considering the lack of studies on the effects of Er:YAG laser irradiation on root surfaces submitted to scaling and root planing, the aim of the present study is to evaluate such effects by means of scanning electron microscopy, utilizing Er:YAG laser with two energy parameters.

\section{MATERIAL AND METHODS}

Nine roots of sound young human premolars, without periodontal disease, hypoplastic defects or restorations, had been utilized in this study. All teeth had been extracted for orthodontic reasons.

\section{Preparation of test specimens}

After extraction, the teeth were cleansed from blood and other debris and kept in saline solution at $37^{\circ} \mathrm{C}$ for a maximum period of six months, in order to maintain hydration. With a high-speed bur, parallel grooves were confected on the mesial and distal surfaces of teeth: one at the enamel-cement junction and the other $5 \mathrm{~mm}$ away, in apical direction, in order to delimitate the cervical third of the roots.

After the groves were confected, a small amount of cement was removed with a high-speed bur, by means of ten movements, from the apical to the cervical region. After this procedure, the roots (mesial and distal aspects) were scaled and planed with a 5-6 Gracey instrument (Hu-Friedy ${ }^{\circledR}$ - USA), by means of 50 vertical tension movements, on the area delimitated by the grooves. Eighteen 1-mm-thick fragments measuring $3 \times 3 \mathrm{~mm}$ were obtained by means of a low-speed saw (Isomet - USA) with a diamond disc, under deionized water.

\section{Experimental procedures}

The specimens were rinsed with saline solution and randomly assigned to three groups with six specimens each, receiving the following treatments:

- Group 1 (G1 - control group) - scaling and root planing + irrigation with saline solution;

- Group 2 (G2) - scaling and root planing + Er:YAG laser $(2.94 \mu \mathrm{m})$ irradiation (Kavo Key Laser - KaVo - Germany) with the following parameters: $100 \mathrm{~mJ} / 47 \mathrm{~mJ}$ (corresponding to a $57 \%$ transmission factor), $10 \mathrm{~Hz}, 15$ seconds of irradiation in a total of 150 pulses, $0.57 \mathrm{~J} / \mathrm{cm}^{2}$, followed by irrigation with $10 \mathrm{ml}$ of saline solution.

- Group 3 (G3) - scaling and root planing + Er:YAG laser $(2.94 \mu \mathrm{m})$ irradiation (Kavo Key Laser KaVo - Germany) with the following parameters: $140 \mathrm{~mJ} / 83 \mathrm{~mJ}$ (corresponding to a $57 \%$ transmission factor), $10 \mathrm{~Hz}, 15$ seconds of irradiation in a total of 150 pulses, $1.03 \mathrm{~J} / \mathrm{cm}^{2}$, followed by irrigation with $10 \mathrm{ml}$ of saline solution;

The G2 and G3 specimens were irradiated with the Er:YAG laser $(2.94 \mu \mathrm{m})$, with a pulse width varying from 250 to $500 \mathrm{~ms}$, with a 2,056 handpiece and fiber dimensions of $1.65 \times 0.5 \mathrm{~mm}$, with a transmission factor of $57 \%$, focused, without contact $(0.5 \mathrm{~mm})$ with the fiber, which was placed perpendicularly to the irradiated surface, with air/water jet cooling. The specimens were mounted on an iron platform and stabilized with a double-face adhesive tape for Er:YAG laser irradiation.

Following irradiation, the specimens were identified and kept in a $2.5 \%$ glutaraldehyde in $0.1 \mathrm{M}$ buffered phosphate solution ( $\mathrm{pH} 7.4$ ) for a minimum period of 24 hours. The specimens were then cleansed by means of three irrigation cycles with $10 \mathrm{ml}$ of a $0.1 \mathrm{M}$ buffered phosphate solution. They were submitted to a sequential dehydration process with $70 \%$ alcohol (10 minutes); $80 \%$ alcohol (10 minutes); $90 \%$ alcohol (10 minutes) and 100\% alcohol (10 minutes). The specimens were then dried at room temperature to enable the sputtering process with gold, with $99.9 \%$ vacuum purity. Sputtering was carried out by means of a specific equipment (Baltec - SCD - 050) set for $120 \mathrm{sec-}$ onds, which produced a 25-nm gold film. The specimens were then positioned for SEM analysis with $20 \mathrm{Kv}$ (Philips - EDAX). 
Theodoro LH, Garcia VG, Haypek P, Zezell DM, Eduardo C de P. Morphologic analysis, by means of scanning electron microscopy, of the effect of Er:YAG laser on root surfaces submitted to scaling and root planing. Pesqui Odontol Bras 2002;16(4):308-312.

\section{RESULTS Group 1}

The root surfaces from this group presented an exposed dentinal layer; moderate smear layer was observed in one specimen and five specimens presented intense smear layers with evidence of opened dentinal tubules (Figure 1).

\section{Group 2}

Five specimens from this group presented no smear layer on the dentinal root surface as well as totally closed dentinal tubules. One specimen presented partially closed dentinal tubules. The analyzed surfaces presented irregularities and were characterized by the presence of superposed flaky areas with absence of grooves, fractures, cracks, fusion or charring in all specimens (Figure 2).

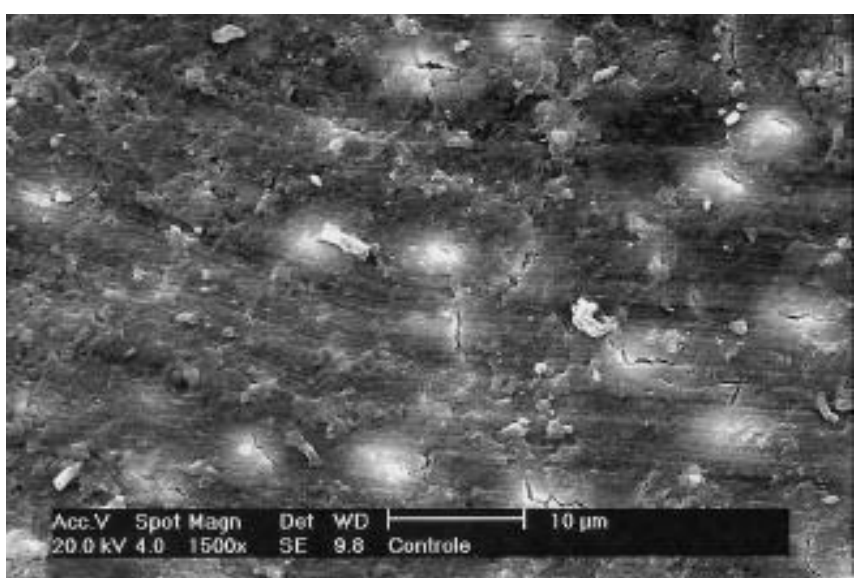

FIGURE 1 - Group 1: root surface with regular aspect, strong presence of smear layer and evidence of opened dentinal tubules.

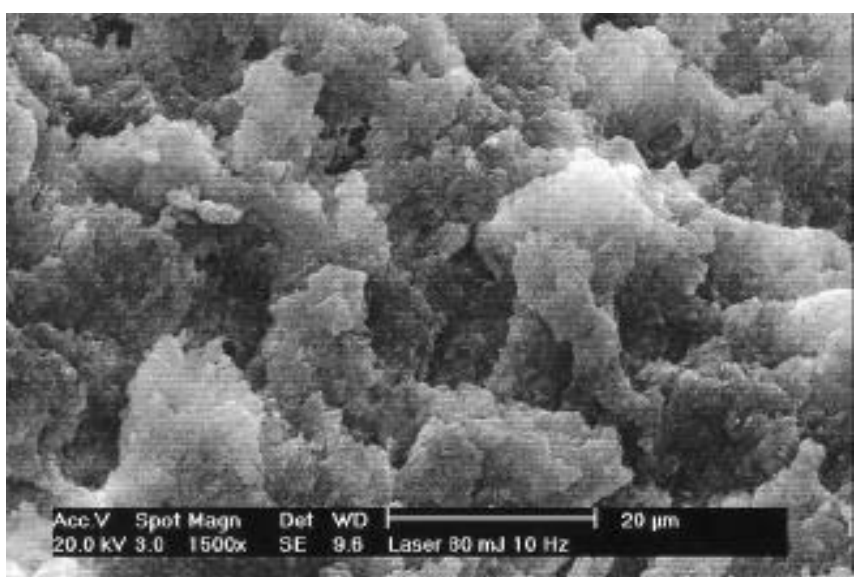

FIGURE 2 - Group 2: root surface with irregular aspect, absence of smear layer and partially opened dentinal tubules.

\section{Group 3}

The specimens from Group 3 were the most uniform, when compared with those of the other groups. All the analyzed specimens presented the same characteristics: absence of smear layer and totally opened dentinal tubules. They presented irregular surfaces with superposed flaky areas, without grooves, cracks, fractures or charring, but the presence of exposed dentinal tubules was uniform in all specimens (Figure 3).

\section{DISCUSSION}

Based on the analysis of the results we could note that, in G1 (control) specimens, which were manually scaled and root planed with manual curettes, there was intense smear layer formation. The presence of striation caused by manual instrumentation (Figure 1) is in total accordance with previous findings of other authors ${ }^{1,2,25,26}$.

Regarding the groups treated with Er:YAG laser, we could observe that G2 specimens presented with an irregular aspect (with elevations and depressions, both in the same orientation) due to the explosive ablation caused by laser irradiation. In G3, the utilized irradiation parameters were capable of removing the smear layer from the root surface, and all specimens presented exposed dentinal tubules without intratubular smear layer (Figure 3). This fact demonstrates the great effectiveness of the energy applied on G3 - it was more able to expose dentinal collagen fibers, completely removing the smear layer. According to some authors, that might be an important factor in the insertion of new collagen fibers ${ }^{1,2,26}$.

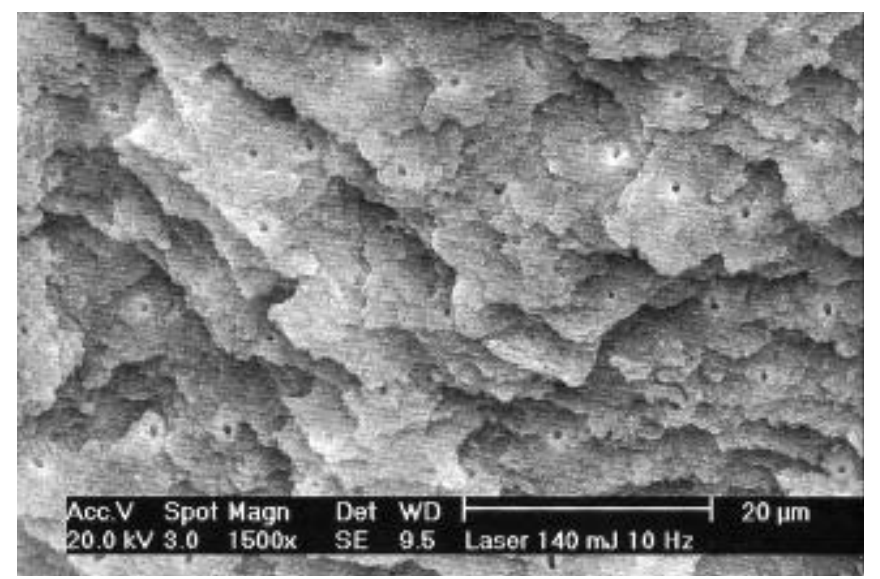

FIGURE 3 - Group 3: root surface with irregular aspect, resembling superposed tissue layers, absence of smear layer and completely opened dentinal tubules. 
Theodoro LH, Garcia VG, Haypek P, Zezell DM, Eduardo C de P.Morphologic analysis, by means of scanning electron microscopy, of the effect of Er:YAG laser on root surfaces submitted to scaling and root planing. Pesqui Odontol Bras 2002;16(4):308-312.

Through electron micrographic analysis, it was possible to observe that although laser was effective in removing the smear layer, it is clear that its action on root surface dentin produced an irregular aspect (Figures 2 and 3), probably due to ablation, although charring, cracks and fractures were not observed. That has also been reported by other authors ${ }^{5,15,16,21}$.

The utilization of lasers to promote scaling and root planing has arisen many controversies. Some studies with Nd:YAG laser have demonstrated that irradiation of root surfaces with certain wavelengths promotes the formation of cracks, fissures, craters and fusion of the mineralized surface ${ }^{14,22}$, specially when laser is used with inadequate irradiation parameters.

On the other hand, the literature has shown, in several studies, that Er:YAG laser has many advantages when compared with Nd:YAG laser, specially when applied to mineralized tissues. Among other explosive ablation lasers, Er:YAG is the most resonant to mineralized surfaces. This fact is due to the high degree of water absorption of its wavelength $(2.94 \mu \mathrm{m})$. This laser acts on mineralized tissues by vaporizing their water, causing micro-explosions and ejection of tissues (explosive ablation) with less thermal damage, specially when it is used with an air/water cooling system ${ }^{15,21,27}$.

Many papers have reported the high bactericidal effect of high-intensity lasers on periodontal pathogenic bacteria, confirming that high-intensity lasers may act as coadjutant instruments in periodontal therapy ${ }^{3,7,17}$. This fact is probably due to the fact that laser irradiation promotes the vaporization of the water present in the cytoplasm of bacteria, thus causing cell rupture.

The scaling and root planing procedure is often not enough to eliminate the toxic agents from root surfaces, such as the outer and inner toxins from bacteria, which are the main reason for periodontal

\section{REFERENCES}

1. Adriens PA, Loesche WJ, De Boever JA. Bacterial invasion in root cementum and radicular dentin of periodontally diseased teeth in humans. J Periodontol 1988;59:222-30.

2. Aleo JJ, De Renzis FA, Farber PA, Varboncoeur AP. The presence and biologic activity of cementum-bound endotoxin. J Periorlontol 1974;45:672-5.

3. Ando Y, Aoki A, Watanabe H, Ishikawa I. Bactericidal effect of Erbium:YAG laser on periodontopathic bacteria. Lasers Surg Med 1996;19:190-200. disease with destructive character. Thus, several chemical agents, such as citric acid, tetracycline and EDTA, were introduced with the aim of removing toxins and reducing the number of bacteria on the root surface. However, clinical studies have demonstrated that the utilization of these chemical agents has no significant effect on the healing process of periodontal tissues ${ }^{11,12,13}$.

In this study, it was possible to observe that Er:YAG laser is capable of removing the debris, which are the products of scaling and root planing (smear layer). However, it does not promote root surface smoothing. In fact, it produces a more irregular surface. It is not clear, in the literature, if this irregular surface interferes with the events related to the healing of periodontal tissues.

\section{CONCLUSIONS}

From the results presented in this study, it is possible to conclude that:

1. the Er:YAG laser-irradiated root surfaces presented, in both utilized parameters, a more irregular aspect, when compared to the control group (without Er:YAG laser irradiation). However, non of the specimens presented with craters, cracks, fusion or charring;

2. when the groups irradiated with Er:YAG laser were compared, it was evident that there was a more efficient removal of smear layer, as well as greater exposure of dentinal tubules, in the specimens from Group $3\left(87 \mathrm{~mJ}, 10 \mathrm{~Hz}, 1.03 \mathrm{~J} / \mathrm{cm}^{2}\right.$, $15 \mathrm{~s})$.

\section{ACKNOWLEDGMENTS}

The authors would like to thank FAPESP (São Paulo State Research Foundation ), grant number 97/ 10823-0, and LELO - Experimental Laboratory of Lasers in Dentistry, School of Dentistry, University of São Paulo, for the laser equipment utilized in this study.

4. Aoki A, Ando Y, Watanabe $\mathrm{H}$, Ishikawa I. In vitro studies on laser scaling of subgingival calculus with an Er:YAG laser. J Periodontol 1994;65:1097-106.

5. Aoki A, Miura M, Akiyama F, Nakagawa N, Tanaka J, Oda $J$, Watanabe $H$. In vitro evaluation of Er:YAG laser scaling of subgingival calculus in comparison with ultrasonic scaling. J Periodont Res 2000;35:266-76.

6. Baker PJ, Rotch HA, Trombelli L, Wikesjo UME. An in vitro screening model to evaluate root conditioning protocols 
Theodoro LH, Garcia VG, Haypek P, Zezell DM, Eduardo C de P. Morphologic analysis, by means of scanning electron microscopy, of the effect of Er:YAG laser on root surfaces submitted to scaling and root planing. Pesqui Odontol Bras 2002;16(4):308-312.

for periodontal regenerative procedures. J Periodontol 2000;71:1139-43.

7. Ben Hatit Y, Blum R, Severin C, Maquin M, Jabro MH. The effects of a pulsed Nd:YAG laser on subgingival bacterial flora and on cementum: an in vivo study. J Clin Laser Surg Med 1996;14(3):137-43.

8. Bergenholtz A, Babay N. Scanning electron microscopy of the root surface texture of extracted periodontally diseased teeth following various etching and chelating regimens. Int J Periodont Rest Dent 1996;18(2):171-9.

9. Blomlöf J, Blomlöf LB, Lindskog SF. Smear removal and collagen exposure after non-surgical root planning followed by etching with an EDTA gel preparation. J Periodontol 1996;67:841-5.

10. Blomfof JPS, Blomlof LB, Lindskog SF. Smear layer formed by different root planing modalities and its removal by an ethylenediamintetracetic acid gel preparation. Int J Periodont Rest Dent 1997;17:243-9.

11. Blomlof L, Bergamn E, Forsgardh A, Foss L, Larsson A, Sjoberg B et al. A clinical study of root surface conditioning with an EDTA gel. I - nonsurgical periodontal treatment. Int J Periodont Rest Dent 2000;20:561-5.

12. Blomlof L, Jonsson B, Blomlof J, Lindskog S. A clinical study of root surface conditioning with an EDTA gel. II surgical periodontal treatment. Int $J$ Periodont Rest Dent 2000;20:567-73.

13. Caffesse RG, Nasjleti CE, Anderson GB, Lopatin DE, Smith BA, Morrison EC. Periodontal healing following guided tissue regeneration with citric acid and fibronectin application. J Periodontol 1991;62:21-9.

14. Cobb CM, Mccawley TK, Killoy WJ. A preliminary study on the effects of the Nd:YAG laser on root surfaces and subgingival microflora in vivo. J Periodontol 1992;63:701-7.

15. Folwaczny M, Mehl A, Haffner C, Benz C, Hickel R. Root substance removal with Er:YAG laser radiation at different parameters using a new delivery sistem. J Periodontol 2000;71:147-55.

16. Fujii T, Baehni PC, Kawai O, Kawakami T, Matsuda K, Kowashi Y. Scanning electron microscopic study of the effects of Er:YAG laser on root cementum. J Periodontol 1998;69:1283-90.

17. Gutknecht N, Fischer J. Bacterial effect of the Nd:YAG in laser-supported curetage. Int Simposium on Biomedical Optics 1997;6:2973-9.
18. Hatfield CG, Baumhammers A. Cytotoxic effects of periodontally involved surfaces of human teeth. Arch Oral Biol $1971 ; 16: 465-8$.

19. Higashi $T$, Okamoto $H$. The effect of ultrasonic irrigation before and after citric acid treatment on collagen fibril exposure: an in vitro SEM study. J Periodontol 1995;66:887-91.

20. Isik AG, Tarim B, Hafez AA, Yalcin FS, Onan U, Cox CF. A comparative scanning electron microscopic study on the characteristics of demineralized dentin root surface using different tetracycline $\mathrm{HCl}$ concentrations and application times. J Periodontol 2000;71:219-25.

21. Israel M, Cobb CM, Rossmann JA, Spencer P. The effects of $\mathrm{CO}_{2}$, Nd:YAG and Er:YAG lasers with and without surface coolant on tooth roots surfaces. An in vitro study. J Clin Periodontol 1997;24:595-602.

22. Ito K, Nishikata J, Murai S. Effects of Nd:YAG laser radiation on removal of a root surface smear layer after root planing. A scanning electron microscopic study. J Periodontol 1993;64:547-52.

23. Keller U, Hibst R. Experimental removal of subgingival calculus with the Er:YAG laser. Proc. SPIE 1987;2623:189-98.

24. Lafferty TA, Gher ME, Gray JL. Comparative SEM study on the effect of acid etching with tetracycline $\mathrm{HCl}$ or citric acid on instrumented periodontally-involved human root surfaces. J Periodontol 1993;64:689-93.

25. Pashley DH. Smear-layer: physiological considerations. Oper Dent 1994;3:13-29.

26. Polson AM, Caton J. Factors influencing periodontal repair and regeneration. J Periodontol 1982;53:617-25.

27. Schoop U, Moritz A, Maleschitz K, Goharkhay K, Kluger W, Wernisch J, Sperr W. The impact of Er:YAG laser irradiation on root surfaces: an in vitro evaluation. $J$ Oral Laser Applications 2001;1:35-41.

28. Schwartz Z, Lohmann CH, Wieland M, Cochran DL, Deanm DD, Textor M, Bonevald LF, Boyan BD. Osteoblast proliferation and differentiation on dentin slices are modulated with tetracycline or osteoclasts. J Periodontol 2000;71:586-97.

29. Schwartz F, Sculean A, Georg T, Reich E. Periodontal treatment with an Er:YAG laser compared to scaling and root planing. A controlled clinical study. J Periodontol 2001;72:361-7.

30. Trombelli L, Sabbia A, Zangari F, Griselli A, Wikesjo UME, Calura G. Effect of tetracycline $\mathrm{HCl}$ on periodontally affected human root surfaces. J Periodontol 1995;66:685-91. 